\title{
Is Tourism Just Another Commodity? Links between Commodity Trade and Tourism
}

\author{
Stephen T. Easton \\ Simon Fraser University
}

\begin{abstract}
Commodity trade and international tourism may be linked through substitution on the supply side or by substitution or complementarity on the demand side. Simple correlation reveals a positive association between international tourism to and commodity exports from Canada. A model incorporating both tourism and exports provides evidence of substitutability between them. Such a link implies that export promotion or tourism promotion may work at cross purposes. (JEL Classification: F14)
\end{abstract}

\section{Tourism and Trade}

Although international tourism constitutes a growing component of expenditure among nations, trade economists have been relatively slow to inquire into the patterns of tourisms development and expansion. One can search in vain for any mention of international tourism in major international economics textbooks, and most courses that mention tourism are typical-

* Correspondence Address: Department of Economics Simon Fraser University Burnaby, B.C. V5A 1S6 Canada, (Tel) 604-291-3508, (Fax) 604-291-5944, (E-mail) easton@sfu.ca; I am indebted to Patrick Conway and the many discussants at the 1996 International Economics and Finance Society Conference on International Trade, Finance and Economic Development.

(C)1998 - Institute for International Economics, Sejong Institution. All rights reserved. 
ly found in the school of hotel management or practical business training. Yet world tourism is a substantial phenomenon and its growth is likely to continue.

What theory there is about tourism tends to focus on demand and sees tourism as a function of the usual prices and costs. There are various approaches that can be taken to modeling. Harris and Easton [1996] use a Ricardian framework, but identify specific factor and differentiated products models that may be fruitful as well. This paper poses a less theoretical set of questions to ask whether tourism and commodity trade are associated empirically. From a supply side perspective, it is likely that the production of tourism services and the production of physical goods and other services trade-off. Making a French car and providing French hotel tourist services both absorb labor and capital among other factors. On the demand side there is no necessary substitutability or complementarity - at least from the usual basic theory. On the one hand, one can imagine that the allure of French perfume is sufficient to give the purchaser a desire to visit France and partake of the French experience. On the other hand, one can equally believe that by purchasing and drinking French wine in your own country, that consumption acts as substitute for visiting France. ${ }^{1}$ However, as an empirical matter, characterizing the relationship between tourism and commodity trade is both interesting and potentially useful if some underlying systematic relationship can be established for particular countries or as a general proposition among particular goods.

Currently the study of world tourism development is difficult. Although some information about the arrival of tourists at the frontiers of a country or the number of nights spent by tourists in formal accommodation are available for many of the more developed economies, not all countries collect data consistently or survey to record tourist expenditures. It is also difficult to distinguish within country (local if you will) tourism from international

1. The problem could just as easily cast the other way. By visiting France, do I increase desire (demand) for French things? Alternatively, by visiting France do I satiate my desire for "Frenchness" and thus reduce my consumption of French exports? The notion of "rational addiction" might be relevant at some stage, but for reasons discussed below in the section "Exports", it is probably premature to refine this particular data set. 
tourism. On the production side, how can one distinguish components of the supply of tourism goods and services on a consistent basis? There is little that distinguishes restaurant meals for tourists from those of the general population, or hotel accommodations for business purposes from those serving the needs of tourists.

Most studies of tourism are empirical ${ }^{2}$ and focus on the demand for services when a multi-country approach is taken, or look at demand for specific sites in a partial equilibrium context [Crouch, 1995.] These studies have examined both individual country demands and systems of interrelated demands among countries. Yet in most countries there is no set of national accounts that identifies tourism as an explicit component of demand and supply as is done for building, residential housing, automobiles, and the like. As a result, not only the theory but the empirical verification of the significance and growth of international tourism is severely constrained. Measures of international tourism such as arrivals at frontiers or nights spent in accommodation are seldom matched by the systematically relevant categories of expenditures made by tourists on domestic goods and services. Although there are occasional estimates of expenditures by tourists for all countries, and some estimates that are made by every country, tourist specific domestic accounting would be an important way of verifying the activity that appears by all current measures as one of the most important growth industries of the 21 st century.

\section{The Growth of Tourism}

As best it can be measured, international tourism is growing by leaps and bounds. Table 1 highlights the growth in the rates of tourism by describing the growth in tourism arrivals at the frontiers of countries from 1950-1992. The figure in the first column is all arrivals and the second column reports arrivals per thousand of world population. After more than doubling in the decade of the 1950s, per capita arrivals doubled again in the next decade and again in the decade of the 1980s. By 1990, the number of raw arrivals was more than 18 times that of 1950 while per capita arrivals had increased

2. However see Copeland [1991] for an exception. 
Table 1

World Tourism Growth, 1950-1992

\begin{tabular}{|c|c|c|}
\hline Year & $\begin{array}{c}\text { International tourist } \\
\text { arrivals (000) }\end{array}$ & $\begin{array}{c}\text { Trips per thousand } \\
\text { of World Population }\end{array}$ \\
\hline 1950 & 25,282 & 10.05 \\
1960 & 69,296 & 23.24 \\
1965 & 112,729 & 34.28 \\
1970 & 159,690 & 44.24 \\
1975 & 214,357 & 54.04 \\
1980 & 287,906 & 64.70 \\
1985 & 329,636 & 67.97 \\
1990 & 455,594 & 86.52 \\
1991 & 455,100 & 84.53 \\
1992 & 475,580 & 87.49 \\
\hline
\end{tabular}

Sources: World Travel Yearbook, 1994; Statistical Abstract of the United States, various issues

more than eightfold.

Table 2 contrasts the growth of world tourism with that of commodity trade. The first column reports estimated receipts from world international tourism. The second column describes the value of world imports as a measure of trade growth. The final column is the ratio between world international tourism receipts and the value of world imports. The key observation is that by looking at the final column one can see that world tourism growth is even faster than the growth in world trade which itself has been growing rapidly over the past forty years. Although the value of world trade clearly exceeds that of tourism, tourism expenditures relative to trade is growing.

The study of international (and possibly national) tourism by trade theorists is as yet undeveloped, however the phenomenon of tourism itself is substantial in terms of numbers of people travelling and values of their expenditures both at current levels and in rates of growth. With a 1992 value of $\$ 280$ billion US dollars, this industry is larger than most countries national products. The rate of growth of international arrivals per capita is about 5.2 percent per year, but the growth in tourism receipts as a share of world merchandise trade imports suggests that while tourism and trade 
526 Is Tourism Just Another Commodity? Links between Commodity Trade and Tourism

Table 2

The Levels of International Tourism and

Commodity Trade Growth: 1950-1992

\begin{tabular}{|c|c|c|c|}
\hline \multirow{2}{*}{ Year } & $\begin{array}{c}\text { International } \\
\text { tourism receipts }\end{array}$ & World Imports & $\begin{array}{c}\text { Tourism as a } \\
\text { Share of Imports }\end{array}$ \\
\cline { 2 - 4 } & \multicolumn{2}{|c|}{ billions of US \$ } & \\
\hline 1950 & 2 & 79 & $2.7 \%$ \\
1960 & 7 & 136 & $5.0 \%$ \\
1970 & 18 & 329 & $5.4 \%$ \\
1980 & 102 & 2,047 & $5.0 \%$ \\
1990 & 255 & 3,563 & $7.1 \%$ \\
1992 & 279 & 3,805 & $7.3 \%$ \\
\hline
\end{tabular}

Sources: Harris and Easton [1996], World Travel Yearbook, 1994; Statistical Abstract of the United States, various issues.

grew together in the 1960-1980 period, the 1980s and early 1990s have seen a comparatively rapid expansion of tourism spending.

\section{A. Some Basics}

The next part of this paper develops an analytical framework in which to examine trade and tourism for a single country, Canada for which data are relatively easily available. But in looking at the relationship between Canada and its trading and touring partners, I will exclude the biggest trader and provider of tourists to Canada of all: the United States. ${ }^{3}$ The reason for doing this is that as a pair of countries isolated on the northernmost part of North America, the trade and tourist relationships are different from those between Canada and the rest of the world. In particular, distance is easier to characterize when it is from Europe or Asia. The trade patterns between Canada and the US are also more extensive than with any other country, and with integrated production of automobiles across the border, and recent

3. The U.S. provides about 89 percent of all arrivals at Canadian frontiers. However, as might be expected from their proximity, they do not spend in proportion to their numbers. Although the Japanese provide less than $2 \%$ of arrivals at Canadian frontiers, they spend fully $20 \%$ as much as U.S. tourists. 
freer trade arrangements of the Free Trade Agreement and then the North American Free Trade Agreement, the characteristics of US-Canadian trade deserve a separate treatment of their own.

\section{B. The Demand for Commodities and Tourism}

The demand by foreign countries both for Canadian goods and for Canadian tourism services is a function of the usual prices and quantities. For example, if for $n$ goods and services utility is of the form ${ }^{4}$

$$
\begin{gathered}
U(X)=\Sigma a_{i} \log \left(x_{i}-b_{i}\right) \text { for which } a_{i}>0 \text { and }\left(x_{i}-b_{i}\right)>0 \\
\text { and } \sum a_{i}=1, \text { and } i=1, \ldots, n
\end{gathered}
$$

and

$$
\Sigma p_{i} x_{i}=y,
$$

then the Marshallian demand for each $x_{i}$ is

$$
x_{i}=b_{i}-\left[\left(a_{i} / p_{i}\right) \sum_{p_{i}} b_{i}\right]+\left(a_{i} / p_{i}\right) y .
$$

Thus the demand for any good or service depends upon the prices of all goods and services and income.

Although this system is frequently estimated in the form of share equations, it is not possible to do so in this context. As is described below, the data are not sufficiently refined to permit a system estimate of the share equations. More generally, however, let there be a demand for goods imported from Canada, $X$, tourism to Canada, $Y$, and other goods, $Z$, dependent upon prices and income. The price vector is written so as to emphasize the price of Canadian goods and tourism with other commodities and services from both home and abroad suppressed into $p_{z}$, and foreign income, $y^{*}$.

$$
\begin{aligned}
& X=\alpha\left(p_{x}, p_{y}, p_{z}, y^{*}\right) \\
& Y=\beta\left(p_{x}, p_{y}, p_{z}, y^{*}\right) \\
& Z=\gamma\left(p_{x}, p_{y}, p_{z}, y^{*}\right) .
\end{aligned}
$$

4. This is the familiar linear expenditure system formulation. See, for example, Pollak and Wales [1992]. 
This system represents the demand by foreigners for Canadian goods, $X$, and Canadian tourism services, $Y$, which for simplicity are assumed to be uniquely produced in Canada, and for all other goods and services, $Z$. For a given level of expenditure and prices, the budget constraint implies that demands for only two of the three goods are independent so that $\gamma=(1-\alpha-\beta)$.

It is reasonable to assume that all participants in Canadian tourism are small which means that the relative prices of $X$ and $Y$ are not dependent on the number of tourists arriving in Canada from any one source country. The price of all other goods in the foreign economy, $p_{z}$, are also independent of the amount that is spent on tourism in Canada or Canadian goods purchased. Similarly, feedback effects on income are ignored. That is, Canadian income is not so significantly affected by tourism from or exports to any one country that it has an impact on that country's income. Since non-US tourism is a small part of total tourism to Canada, it is also reasonable to assume that the price of tourism is independent of the quantities supplied. The same propositions apply to commodity trade as well. The US takes 80 percent of Canadian exports by value. It is reasonable to assume that commodity prices facing foreign countries are independent of individual national demands.

Although the linear expenditure system described above provides one motivation for the ingredients of individuals demands, it is convenient to write the foreign demand for Canadian goods, $X$, and foreign demand for tourism in Canada, $Y$ as two independent log-linear equations.

$$
\begin{aligned}
& \ln X=\alpha_{0}+\alpha_{1} \ln p_{x}+\alpha_{2} \ln p_{y}+\alpha_{3} \ln p_{z}+\alpha_{y} \ln y^{*}+u_{x} \\
& \ln Y=\beta_{0}+\beta_{1} \ln p_{x}+\beta_{2} \ln p_{y}+\beta_{3} \ln p_{z}+\beta_{y} \ln y^{*}+u_{y},
\end{aligned}
$$

There are the usual homogeneity restriction: the sums of the coefficients on prices add to zero in each equation and there are cross equation restrictions on the substitution elasticities. The cross-section-time-series requires explicit account to be taken of autocorrelation and heteroskedasticity, and more will be said about system estimation in the final section although it will not be the focus of the analysis. In this study there is a pooled time series and cross section sample of 18 countries over a period of twenty-one years: 
from 1972-1992. ${ }^{5}$ The countries are those for which tourism data were available and who were in some measure commodity traders with Canada. ${ }^{6}$ The first question is one of basic data relationships. What metric is appropriate to examine the number of tourists and the amount of trade that takes place?

\section{Exports}

The question is whether there is a systematic relationship between the price or quantity of goods exported by Canada to a trade-partner country and the number of tourists who are sent by that country to Canada. Exports do not provide as fine a distinction as one might wish. Since the theory of final demand is probably what is important in terms of a nations' tourism, one would ideally prefer final or consumer goods rather than also include intermediate goods such as coal or timber. Although there may well be a case for Canadian content in fish, furs, and even wheat and other more manufactured products, our data are for aggregate exports. A more extensive analysis would develop a relationship between particular goods and tourism rather than the broad category of all merchandise exports.

\section{Tourism}

I use at the number of arrivals at the frontier as the measure of tourism. This would seem to be an unambiguous sort of measure, but it does not actually report the number of individuals visiting or how long they stay. For example. it does not take account of someone who visits Canada and the US in the same trip and bounces back and forth between them. However it does have the virtue of being a measure that is available for a large number of countries, and one of the few measures that Canadians collect systematically

5. In addition to Canada, Belgium, Denmark, France, Germany, Greece, Hong Kong, India, Italy, Japan, Korea, Portugal, Netherlands, New Zealand, Spain, Sweden, Switzerland, and the U.K are included.

6. I will not explore the question of which countries do or do not trade, or which countries are not source countries for tourism. This kind of decision while an interesting one, involves data requirements that are less easily met than those discussed in this paper. 
over a twenty year period. Canada does not collect data about nights spent in hotels or nights spent by tourists - other common measures of tourism.

\section{E. Basic Correlations Between Exports and Tourism}

Trade and tourism data can be organized either as a cross section or as a time series. The first figure scatters the data as a cross section for the year 1992, the latest year for which all the data used in this and subsequent sections are available. The vertical axis, LT92, is the (log of the) number of tourists arriving in Canada per capita of the sending country, and the x-axis is $L X 92$, (the log of) Canada's real exports to that country per capita (of the receiving country.)

The association seen in the scatter plot is borne out by the regression in Table 3. There is a positive cross sectional relationship between the number of tourists sent to Canada and the value of exports received from Canada. Furthermore, the elasticity of tourists and exports is not significantly different from unity at the five percent confidence level. This particular result holds for every year individually from 1972. In no case is the regression coefficient different from unity on the basis of the usual tests.

Although the data are not ideal insofar as there is a comparison of a quantity (of tourists) with a real value of exports (suitably scaled), nonetheless it

Figure 1

\section{Arrivals and Exports}

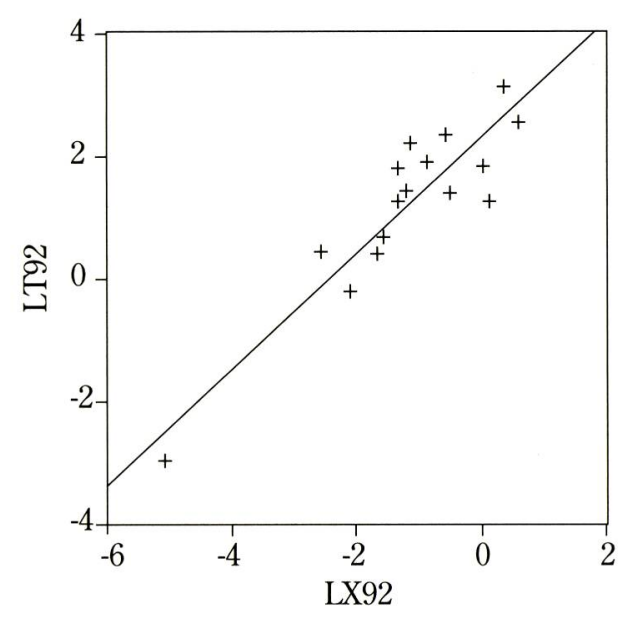


Table 3

Dependent Variable Log of Tourists Arriving in Canada per capita in 1992

\begin{tabular}{|l|c|l|c|}
\hline \multicolumn{1}{|c|}{ Variable } & Coefficient & \multicolumn{1}{c|}{ Std. Error } & $t$-Statistic \\
\hline C & 2.294495 & 0.193474 & 11.85942 \\
\hline LX92 & 0.936024 & 0.111204 & 8.417210 \\
\hline R-squared & 0.825275 & Mean dependent var & 1.199896 \\
\hline Adjusted R-squared & 0.813627 & S.D. dependent var & 1.368152 \\
\hline S.E. of regression & 0.590644 & 17 Observations \\
\hline F-statistic & 70.8494 & \multicolumn{3}{|l}{} \\
\hline
\end{tabular}

is interesting that the quantities appear to increase in proportion. As has been suggested above, there is no necessary reason for this to be the case although it is natural to assume that if similar forces, such as real income (for example) drive both, such an association is reasonable.

\section{F. Time Series}

In the case of the 17 countries trading with Canada, the individual simple time series relationships between tourism and exports are more varied. In the individual regressions reported in Table 4, all have been adjusted for first order autocorrelation. ${ }^{7}$ In the time series, the coefficients linking (the logarithms of) Tourism to Exports range between being not significantly different from zero and not significantly different from unity.

As is apparent, the point estimates cluster around 0.3 , but there is plenty of dispersion. Although this point will not be explored, the pattern of high relative elasticity in the cross-section averages at a point in time, and the lower average annual results is an interesting puzzle. ${ }^{8}$

As a raw correlation with both the cross-section and time series there is a

7. A second order autocorrelation was considered for Portugal and Spain, but the coefficient results were not sensitive to the correction.

8. Economists are used to the other kind of relationship based on an errors in variables or permanent versus transitory income approach. That is, they would not be surprised at a high coefficient between exports and tourism in the "long run" (time series) and a low coefficient in the "short run" (cross section.) 
Table 4

The Coefficients of Tourism to Exports on a Country by Country Basis: 1972-1992

\begin{tabular}{|c|c|c|c|}
\hline Variable & Coeff. & Std. Error & $t$-Stat. \\
\hline LX2PAUS & 0.30 & 0.08 & 3.84 \\
\hline LX2PBEL & 0.56 & 0.13 & 4.20 \\
\hline LX2PDEN & 0.31 & 0.12 & 2.56 \\
\hline LX2PFRA & 0.47 & 0.16 & 2.95 \\
\hline LX2PGER & 0.33 & 0.14 & 2.39 \\
\hline LX2PGRE & 0.10 & 0.07 & 1.36 \\
\hline LX2PHK & -0.09 & 0.10 & -0.86 \\
\hline LX2PIND & -0.04 & 0.21 & -0.21 \\
\hline LX2PITA & 0.31 & 0.11 & 2.81 \\
\hline LX2PJAP & 0.39 & 0.13 & 2.92 \\
\hline LX2PNET & 0.36 & 0.10 & 3.48 \\
\hline LX2PNZ & 0.12 & 0.20 & 0.60 \\
\hline LX2PPOR & 0.08 & 0.12 & 0.65 \\
\hline LX2PSPA & 0.22 & 0.14 & 1.56 \\
\hline LX2PSWE & 0.33 & 0.14 & 2.33 \\
\hline LX2PSWI & 0.10 & 0.06 & 1.79 \\
\hline LX2PUK & 0.46 & 0.17 & 2.76 \\
\hline
\end{tabular}

tendency for exports and tourism to be associated in a positive way. But to have a simple correlation is not the same as having a model. Both tourism and exports are likely to be functions of the same variables, and as income and populations have been growing around the world, some of the positive association between the two is undoubtedly due to common sources of demand.

\section{A Model of Exports}

\section{A. Merchandise Exports}

Table 5 considers the demand for Canadian exports by the foreign countries in the absence of any interactions with tourism. In this time series cross section, the dependent variable is the logarithm of the real quantity of 
Canadian exports to each country $L R C X T$ ? in which the ? denotes each of the 17 foreign countries in the sample. ${ }^{9}$

The independent variables (in natural logs) are the real per capita gross domestic product measured in US dollars, $L R Y$ (World Bank data); the log of population, $L P O P$; and the real exchange rate defined as the amount of foreign currency per unit of Canadian currency, $L R E X$. Thus an increase in $L R E X$ means that it takes more foreign currency to purchase a real unit of Canadian currency so that the expected sign is negative. The relative price of exports is taken to be the (log of the) ratio of export prices to the Canadian $C P I, L(P X / P)$. It is assumed to be the relevant supply price. ${ }^{10}$

In the table the estimated coefficients, and test statistics are self explanatory. All equations have been corrected for serial autocorrelation. As a general rule, after this first table, the reported autoregressive structure of the model will be suppressed as it adds pages to output and holds little of interest in this study.

The coefficient on real income is positive and significantly different from zero and less than unity at the usual significance level of five percent. The same can be said for population. The effect of the real exchange rate is that an increase in the real exchange rate tends to lower the quantity of exports with an estimated point elasticity of about -0.25 . Finally the estimated price elasticity of demand - in this very simple framework captured by the price of exports relative to the $C P I$ in Canada, is about -1.1 .

The next table, Table 6 , reports the same model but with an adjustment for country specific, fixed-effects. The consequence of this is that the constant terms in each of the country regressions are permitted to be different. From Table 6 it can be seen that the coefficients are the same sign and of

9. Exports are defined as the value of exports divided by the export price index and are drawn from the Statistics Canada Cansim Main Base. Series D-numbers available on request.

10. I do not have prices for the actual imports by the foreign country from Canada, nor do I have the price index of goods exported from Canada to specific countries. One might be able to construct an export index based on exactly what is exported to each country, but that is not done that here. It would be a reasonable if difficult refinement. I have also ignored potential differences between the supply and demand prices associated with trade impediments. Nonetheless I would expect the measure that we do have to be correlated with the correct measure of relative export price. 
534 Is Tourism Just Another Commodity? Links between Commodity Trade and Tourism

Table 5

Canadian Exports to Our Touring Clientele

Pooled LS // Dependent Variable is LRCXT?

\begin{tabular}{|l|c|c|c|}
\hline \multicolumn{1}{|c|}{ Variable } & Coefficient & Std. Error & $t$-Statistic \\
\hline C & -4.007099 & 1.246971 & -3.213465 \\
\hline LRY? & 0.628754 & 0.060011 & 10.47739 \\
\hline LPOP? & 0.594998 & 0.056359 & 10.55731 \\
\hline LREX? & -0.268390 & 0.031323 & -8.568507 \\
\hline L(PX/P) & -1.081457 & 0.165430 & -6.537239 \\
\hline AUS-AR(1) & 0.424449 & 0.263272 & 1.612204 \\
\hline BEL-AR(1) & 0.992704 & 0.032070 & 30.95381 \\
\hline DEN-AR(1) & 0.973474 & 0.052539 & 18.52873 \\
\hline FRA-AR(1) & 0.476746 & 0.292866 & 1.627861 \\
\hline GER-AR(1) & 0.826566 & 0.217636 & 3.797921 \\
\hline GRE-AR(1) & 0.576004 & 0.137109 & 4.201075 \\
\hline HK-AR(1) & 0.885516 & 0.060890 & 14.54280 \\
\hline IND-AR(1) & 0.177234 & 0.204101 & 0.868365 \\
\hline ITA-AR(1) & 0.987322 & 0.030494 & 32.37717 \\
\hline JAP-AR(1) & 0.991875 & 0.021772 & 45.55738 \\
\hline NET-AR(1) & 0.973529 & 0.067305 & 14.46450 \\
\hline NZ-AR(1) & 0.987325 & 0.120001 & 8.227608 \\
\hline POR-AR(1) & 0.827008 & 0.084849 & 9.746829 \\
\hline SPA-AR(1) & 0.693006 & 0.187551 & 3.695016 \\
\hline SWE-AR(1) & 0.950508 & 0.100504 & 9.457384 \\
\hline SWI-AR(1) & 0.779013 & 0.096626 & 8.062166 \\
\hline UK-AR(1) & 0.944529 & 0.056852 & 16.61392 \\
\hline R-squared & 0.971606 & Mean dependent var & 8.556851 \\
\hline Adjusted R-squared & 0.969730 & S.D. dependent var & 1.264748 \\
\hline S.E. of regression & 0.220043 & Sum squared resid & 15.39715 \\
\hline Log likelihood & 409.5634 & F-statistic & 518.1613 \\
\hline Durbin-Watson stat & 1.990938 & Prob(F-statistic) & 0.000000 \\
\hline
\end{tabular}

Notes: 1. Sample; 1972-1992

2. Total panel observations; 340 


\section{Table 6}

\section{The Demand for Exports Adding Fixed Effects}

Pooled LS // Dependent Variable is LRCXT?

\begin{tabular}{|c|c|c|c|}
\hline Variable & Coefficient & Std. Error & t-Statistic \\
\hline LRY? & 0.914940 & 0.214651 & 4.262461 \\
\hline LPOP? & 0.333635 & 0.415110 & 0.803728 \\
\hline LREX? & -0.375672 & 0.238082 & -1.577912 \\
\hline $\mathrm{L}(\mathrm{PX} / \mathrm{P})$ & -0.940982 & 0.171591 & -5.483851 \\
\hline \multicolumn{4}{|c|}{ AR Corrections made but not reported } \\
\hline \multicolumn{4}{|l|}{ Fixed Effects } \\
\hline AUS-C & \multicolumn{3}{|l|}{-1.080508} \\
\hline BEL-C & \multicolumn{3}{|l|}{0.644512} \\
\hline DEN-C & \multicolumn{3}{|l|}{-2.127729} \\
\hline FRA-C & \multicolumn{3}{|l|}{-0.620781} \\
\hline GER-C & \multicolumn{3}{|l|}{-0.880801} \\
\hline GRE-C & \multicolumn{3}{|l|}{-0.483616} \\
\hline $\mathrm{HK}-\mathrm{C}$ & \multicolumn{3}{|l|}{-0.434431} \\
\hline IND-C & \multicolumn{3}{|l|}{1.251280} \\
\hline ITA-C & \multicolumn{3}{|l|}{-0.130143} \\
\hline JAP-C & \multicolumn{3}{|l|}{15.28725} \\
\hline NET-C & \multicolumn{3}{|l|}{-0.354580} \\
\hline $\mathrm{NZ}-\mathrm{C}$ & \multicolumn{3}{|l|}{-1.843736} \\
\hline POR-C & \multicolumn{3}{|l|}{0.144052} \\
\hline SPA-C & \multicolumn{3}{|l|}{-0.083846} \\
\hline SWE-C & \multicolumn{3}{|l|}{-1.634225} \\
\hline SWI-C & \multicolumn{3}{|l|}{-1.715801} \\
\hline UK-C & \multicolumn{3}{|l|}{-137.0467} \\
\hline R-squared & 0.974314 & Mean dependent var & 8.556851 \\
\hline Adjusted R-squared & 0.971167 & S.D. dependent var & 1.264748 \\
\hline S.E. of regression & 0.214757 & Sum squared resid & 13.92844 \\
\hline Log likelihood & 436.0722 & F-statistic & 572.7711 \\
\hline Durbin-Watson stat & 1.875603 & Prob(F-statistic) & 0.000000 \\
\hline
\end{tabular}

Notes: 1. Sample; 1972-1992

2. Total panel observations; 340 
roughly the same magnitude as they were in the previous table, although the real income coefficient is now not significantly different than unity and the population variable has become insignificant. The mass of coefficients on both the autoregressive term and the fixed effects themselves are not the focus of this paper and in subsequent tables will be suppressed so that the behavioral coefficients may be seen more clearly.

\section{B. Adding Some Richness to the Demand Specification}

In a crude sense the goods export equation is functional. Were there a fully specified demand system, the full range of the prices of substitutes and complements would be included. Although there is no explicit price for international tourism, one possible proxy is the wage rate in the accommodation industry. It provides a measure of the relative price of tourism. If as is generally believed, tourism is a service that relies substantially on person to person activity, then the real wage is a sensible indicator of price although, of course, it would be preferable to have a true price of tourism capturing the weights associated with the different inputs. Table 7 adds the price of tourism as (possibly) captured by the real wage in the accommodation industries. (Recall that the autoregressive and fixed effect parameters have been suppressed for easier reading of the table.)

The problem with this specification is that the real wage, the real exchange rate and the relative price of exports all seem to sufficiently correlated to make distinguishing the individual effects difficult. It may also be that the wage rate is sufficiently related to wages in the rest of the economy that it is proxying for a very different phenomenon. This leaves us with an export demand function in which results are mixed. We have some confidence that Canadian exports to each country is a function of foreign incomes and prices and, more weakly, that it depends upon the exchange rate and real wages within Canada. ${ }^{11}$

By turning to the demand for international tourism, it is possible to get a

11. Further, there is the distinct possibility that the real wage in the accommodation industry is sufficiently correlated with other wages that it has an impact on all exports, not only those in the accommodation industry. Thus the negative sign may reflect more complex processes. 
Table 7

\section{The Demand for Exports Adding The Real Wage} in the Accommodation Industry

Pooled LS // Dependent Variable is LRCXT?

\begin{tabular}{|l|c|l|c|}
\hline \multicolumn{1}{|c|}{ Variable } & Coefficient & Std. Error & t-Statistic \\
\hline LRYU? & 0.899082 & 0.214892 & 4.183882 \\
\hline LPOP? & 0.285085 & 0.410991 & 0.693654 \\
\hline LREX? & -0.335321 & 0.238319 & -1.407026 \\
\hline LOG(PX/P) & -0.590015 & 0.277322 & -2.127544 \\
\hline LRWAGE & -0.877102 & 0.527374 & -1.663149 \\
\hline R-squared & 0.974513 & Mean dependent var & 8.556851 \\
\hline Adjusted R-squared & 0.971295 & S.D. dependent var & 1.264748 \\
\hline S.E. of regression & 0.214280 & Sum squared resid & 13.82064 \\
\hline Log likelihood & 442.2896 & F-statistic & 548.0422 \\
\hline Durbin-Watson stat & 1.892417 & Prob(F-statistic) & 0.000000 \\
\hline
\end{tabular}

Notes: 1. Sample; 1972-1992

2. Total panel observations; 340

stronger read on the degree to which tourism and trade are substitutes or complements. Such a discovery did not emerge very clearly from the export equations.

\section{A Simple Model of Tourism}

The framework for international tourism is similar to the model developed by Harris and Easton [1996]. Like so many models of international tourism, this one too is fundamentally oriented toward demand. The basic equation to be estimated is the demand for tourism to Canada. It is a function of the (logs of) per capita real income in the sending country, $R Y$; the population of the sending country, LPOP; the real exchange rate, LREX; the price of transportation, $L T C R Y$; and relative prices between Canada and the United States, $L(P C / P U S)$ adjusted for the exchange rate. ${ }^{12}$ This latter vari-

12. This is of course the real exchange rate between Canada and the United States written to highlight the relative price levels between the two countries. In effect the rela- 
able is interpreted to reflect the relative price of tourism between the two countries. The (log of) real wage, $L R W A G E$, of those in the accommodation industry is also included in the model. As before, the hope is that this will capture some tourism specific price effects that are not directly observable in the relative price levels between the two countries.

In the model the sign of population is expected to be positive as more people should mean more visitors. Real per capita income, $L R Y$, is also expected to have a positive sign. ${ }^{13}$ The real exchange rate, $L R E X$, defined as the number of real foreign currency units per Canadian dollar is expected to be negative, as a higher real rate means that Canadian vacations are more expensive. The price of transportation is also expected to be negative as more costly travel should diminish the amount of travel. The measure of transportation cost has two ingredients. The first is the cost per mile of air travel multiplied by the distance from each country's major airport to the closest port of entry in Canada. This travel cost is then divided by per capita income in the home country to yield (the log of) transportation cost relative to income, $L T C R Y$. It is the share of average per capita income that the trip to Canada will cost. The (log of the) ratio of the price levels between Canada and the US is expected to capture the phenomenon of substitution insofar as a higher Canadian price level should mean that tourists substitute US for Canadian travel. Real wage in the accommodation industry are included to pick up a component of relevant tourism prices directly. A higher real Canadian wage in the accommodation industry is expected to have a negative sign as higher costs are reflected in higher prices to tourists. This model is estimated with a cross section time series procedure. There are 17 coun-

tive prices ratio is being thought of as if it is the relative price of tourism between the two countries.

13. In contrast to Harris and Easton [1996] I do not explore the age distribution of the sending country's population. Although this is of considerable interest and some importance, in the absence of age-specific incomes, there is no point in complicating the present model in this way. The real income and population terms are often very substantial as they pick-up what may appear to be non-linear effects. Without information about the population-income distribution, it is hard to know whether these high elasticities are artifacts of particular age-income cohorts, or reflect general behavioral responses to higher income and population numbers. 
Table 8

Tourism Demand for Canada

Pooled LS / / Dependent Variable is LARR?

\begin{tabular}{|c|c|c|c|}
\hline Variable & Coefficient & Std. Error & t-Statistic \\
\hline LPOP? & 2.036162 & 0.385730 & 5.278721 \\
\hline LRY? & 0.529917 & 0.267233 & 1.982975 \\
\hline LTCRY? & -0.422418 & 0.112506 & -3.754610 \\
\hline LREX? & -0.324127 & 0.132167 & -2.452416 \\
\hline LOG(PC/PUS) & -0.710197 & 0.214348 & -3.313292 \\
\hline LRWAGE & -0.066565 & 0.206962 & -0.321629 \\
\hline AUS-AR(1) & 0.572144 & 0.182979 & 3.126826 \\
\hline BEL-AR(1) & 0.566012 & 0.264106 & 2.143121 \\
\hline $\mathrm{DEN}-\mathrm{AR}(1)$ & 0.520128 & 0.286864 & 1.813149 \\
\hline FRA-AR(1) & 0.928886 & 0.122123 & 7.606156 \\
\hline GER-AR(1) & 0.644441 & 0.189350 & 3.403447 \\
\hline GRE-AR(1) & 0.624712 & 0.222635 & 2.805989 \\
\hline $\mathrm{HK}-\mathrm{AR}(1)$ & 0.811698 & 0.117069 & 6.933500 \\
\hline IND-AR(1) & 0.307007 & 0.125042 & 2.455236 \\
\hline ITA-AR(1) & 0.262897 & 0.354289 & 0.742039 \\
\hline JAP-AR(1) & 0.940390 & 0.134983 & 6.966734 \\
\hline NET-AR(1) & 0.967231 & 0.295046 & 3.278241 \\
\hline NZ-AR(1) & 0.779694 & 0.085300 & 9.140589 \\
\hline POR-AR(1) & 0.538036 & 0.121106 & 4.442668 \\
\hline SPA-AR(1) & 0.635878 & 0.181008 & 3.512983 \\
\hline SWE-AR(1) & 0.606065 & 0.185340 & 3.270013 \\
\hline SWI-AR(1) & 0.721226 & 0.144746 & 4.982702 \\
\hline UK-AR(1) & 0.829806 & 0.188358 & 4.405486 \\
\hline \multicolumn{4}{|l|}{ Fixed Effects } \\
\hline AUS-C & \multicolumn{3}{|l|}{-26.89081} \\
\hline BEL-C & \multicolumn{3}{|l|}{-28.11764} \\
\hline DEN-C & \multicolumn{3}{|l|}{-26.90496} \\
\hline FRA-C & \multicolumn{3}{|l|}{-29.07251} \\
\hline GER-C & \multicolumn{3}{|l|}{-29.54263} \\
\hline GRE-C & \multicolumn{3}{|l|}{-27.66463} \\
\hline $\mathrm{HK}-\mathrm{C}$ & \multicolumn{3}{|l|}{-24.94319} \\
\hline IND-C & \multicolumn{3}{|l|}{-32.34746} \\
\hline ITA-C & \multicolumn{3}{|l|}{-31.02924} \\
\hline JAP-C & \multicolumn{3}{|l|}{-30.81957} \\
\hline NET-C & \multicolumn{3}{|l|}{-27.45123} \\
\hline $\mathrm{NZ}-\mathrm{C}$ & \multicolumn{3}{|l|}{-24.60841} \\
\hline POR-C & \multicolumn{3}{|l|}{-27.67078} \\
\hline SPA-C & \multicolumn{3}{|l|}{-30.77677} \\
\hline SWE-C & \multicolumn{3}{|l|}{-27.54091} \\
\hline SWI-C & \multicolumn{3}{|l|}{-26.21407} \\
\hline UK-C & \multicolumn{3}{|l|}{-27.65653} \\
\hline R-squared & 0.989099 & Mean dependent var & 10.79970 \\
\hline Adjusted R-squared & 0.987681 & S.D. dependent var & 1.094736 \\
\hline S.E. of regression & 0.121504 & Sum squared resid & 4.428942 \\
\hline Log likelihood & 657.9569 & F-statistic & 1237.248 \\
\hline Durbin-Watson stat & 1.919035 & Prob(F-statistic) & 0.000000 \\
\hline
\end{tabular}

Notes: 1. Sample; 1972-1992.

2. Total panel observations; 340 
tries for which there are arrivals data and 21 years of observations. Table 8 explores the relationship between tourism and the variables described above. It incorporates both a fixed effect and an autoregressive correction. These will be dropped after this table since they are not the focus of the analysis.

In each case the variables in Table 8 have the expected sign although the wage rate in the accommodation industries does not meet the usual significance levels. All of the other coefficients emphasize the strength of the income and relative price effects. The large elasticity of the population coefficient and the comparatively modest coefficient on real income stands in contrast to some results in the recent literature which emphasizes the income effects. It is likely that the income and population effects are important in an age-specific way that is not well captured by the gross figures. Unfortunately, age-specific income distribution data are very difficult to find for these countries and this period. Casual observation suggests that the high elasticities are a consequence of particular age-income groups taking extensive advantage of travel. ${ }^{14}$

Table 9 includes a measure of the relative price of exports to pose the question of the connection between tourism and exports directly. As in earlier tables, the autocorrelation and fixed effect coefficients will be suppressed.

In Table 9 it is apparent that all the variables retain their expected signs, have coefficients that are about the same size and maintain reasonable significance levels. The coefficient for the relative price of Canadian exports is positive. This suggests that an increase in the price of Canadian exports which reduces the demand for Canadian merchandise goods increases the demand for tourists to Canada. There does appear to be at least some evidence of substitutability in demand between goods and tourism services.

14. Harris and Easton [1996] argue that many of the high values of the measured income elasticities of tourism demand probably reflect the interaction of the age and income cohorts with countries rather than necessarily a simple income effect and estimate their model accordingly although adequate measures of income distribution are not available for most countries. 
Table 9

Tourism Demand and the Price of Exports

Pooled LS / / Dependent Variable is LARR?

\begin{tabular}{|c|c|c|c|}
\hline Variable & Coefficient & Std. Error & $t$-Statistic \\
\hline LPOP? & 2.004116 & 0.391675 & 5.116782 \\
\hline LRY? & 0.465211 & 0.270996 & 1.716673 \\
\hline LTCRY? & -0.487268 & 0.119807 & -4.067108 \\
\hline LREX? & -0.262816 & 0.136043 & -1.931860 \\
\hline LOG(PC/PUS) & -0.648629 & 0.217558 & -2.981402 \\
\hline LRWAGE & -0.478125 & 0.318502 & -1.501169 \\
\hline LOG(PX/PC) & 0.261955 & 0.131803 & 1.987698 \\
\hline R-squared & 0.989184 & Mean dependent var & 10.79970 \\
\hline Adjusted R-squared & 0.987738 & S.D. dependent var & 1.094736 \\
\hline S.E. of regression & 0.121226 & Sum squared resid & 4.394055 \\
\hline Log likelihood & 659.6622 & F-statistic & 1188.978 \\
\hline Durbin-Watson stat & 1.883148 & Prob(F-statistic) & 0.000000 \\
\hline
\end{tabular}

Notes: 1. Sample; 1972-1992

2. Included observations; 21

3. Total panel observations; 340

\section{System Estimation}

In principle, the two equations can be estimated as a single system with cross equation restrictions. There are, however, several difficulties. First, because there is no explicit price of tourism, I have identified two possible components of the price: the real exchange rate and the real wage. The cross elasticity of substitution between tourism to the US and tourism to Canada is estimated with the relative price levels. Ideally, were there appropriate satellite accounts, one could estimate the correct weights on a price index that would truly characterize tourism composed of the prices of the goods and services that tourists use.

The nub of the matter is that imposing homogeneity of individual demand and cross elasticity equation demand restrictions is an exercise that is not informative. For example, homogeneity is not rejected if the appropriate 
sum of all price changes in the system are calculated, but it is a weak test as the standard errors are large. Cross equation restrictions on the coefficients suffer from the imprecision of the measure of the price of tourism, but they also suffer from a lack of data about total expenditures on tourism in Canada by country. Consequently, we cannot restrict the cross-elasticities across the two equations.

Finally, system estimates of the two equations (which are not presented here) add little to the estimates in the tables. Seemingly Unrelated Regression (SUR) methods did not converge when the whole data set was employed, and estimates of a variety subsets of the data were usually consistent with the values found in the tables. As a result, the pooled single equation estimates are the most informative way to interpret the data at the present time.

\section{Conclusion}

In contrast to the simple correlational evidence associating increased exports with increased tourism (for which the pattern of time-series and cross-sectional correlations remains a puzzle), there is some evidence of a substitution of Canadian exports for tourist excursions to Canada. This kind of a result suggests that trade economists would do well to focus some attention on the interrelated behavior of commodity exports and tourism. If commodity exports and tourism really do prove to be substitutes for one another, then an export support program or tourism development subsidy generates a more complex chain of price and quantity events than is currently recognized.

\section{References}

Air Transport Association of America. 1301 Pennsylvania Avenue, NW, Suite 1100, Washington, DC 20004-1707 USA. Available as a file: YIELD.WK1 at internet site: http://www.air-transport.org/data/yield.htm

Copeland, Brian R. [1991], "Tourism, Welfare and De-industrialization in a Small Open Economy" Economica 58 (232); pp. 515-29.

Crouch, G. I. [1995], “The Study of International Tourism Demand: A Review 
of The Findings," Journal of Travel Research, Summer; pp. 12-23.

Crouch, G.I. [1992], "The Effect of Income and Price on International Tourism," Journal of Tourism Research 19; pp. 643-664.

Harris, R. G. and S.T. Easton [1996], "International Tourism in the AsiaPacific Region and its Implications for Canada,” in Richard G. Harris ed., The Asia Pacific Region in the Global Economy: A Canadian Perspective, Calgary: University of Calgary Press; pp. 259-300.

Japan, Statistics Bureau Management and Coordination Agency [19701992], Japan Statistical Yearbook, various years.

Lufthansa [1992], OAG Desktop Flight Guide Worldwide, Edition 17(2) April.

Mak, J. and K. White [1992], "Comparative Tourism Development in Asia and the Pacific," Journal of Travel Research, Summer; pp. 14-23.

Organization for Economic Co-operation and Development [1991], Tourism Policy and International Tourism in OECD Member Countries 1990-91, Paris: OECD.

Peterson, John [1988], "Export Shares and Revealed Comparative Advantage: a Study of International Travel Applied," Economics 20; pp. 351365.

Pollak, Robert A. and Terence J. Wales [1992], Demand System Specification and Estimation, New York: Oxford University Press.

Statistics Canada, Cansim Data Base: Monthly arrivals into Canada and Canadian exports to each of the countries. D-numbers available on request.

Travel Industry World Yearbook, The Big Picture 1993-1994, Volume 37.

United States Department of Commerce [1970-1995], Statistical Abstract of the United States various issues.

World Bank [1995], World Tables on World Bank Data on Diskette. 